\title{
Hubungan Penanda Infeksi, Penanda Oksigenasi, dan Faktor Risiko Lainnya terhadap Mortalitas Pasien COVID-19 dengan Pneumonia Saat Admisi di Unit Perawatan Intensif RSUP Dr. Wahidin Sudirohusodo
}

\section{The Relationship of Infection Markers, Oxygenation Marker, and Other Risk Factor toward Mortality of COVID-19 Patient with Pneumonia During Admission at Intensive Care Unit Wahidin Sudirohusodo Hospital}

Andi Taufik Amiruddin ${ }^{\bowtie}$, Haizah Nurdin, Syafri K. Arif, Andi Muh. Takdir Musba, Andi Salahuddin, Ari Santri Palinrungi

Departemen Anestesiologi dan Terapi Intensif, Fakultas Kedokteran, Universitas Hasanuddin, Makassar, Indonesia

${ }^{\square}$ Korespondensi: anditaufikamrddn@gmail.com

\section{ABSTRACT}

Background: World Health Organization (WHO) has declared an emergency situation for the spread of coronavirus disease (COVID-19). Mortality risk factors of COVID-19 critical patients have not been widely studied.

Objective: To determine the correlation between risk factors and pneumonia COVID-19 patients' mortality.

Methods: A retrospective study was conducted at Dr. Wahidin Sudirohusodo Hospital infection centre intensive care unit (ICU), Makassar from April - August 2020. Study sample was COVID-19 patients' data who were admitted to infection centre ICU. Patients were divided into two groups: survivor group (SG) and non-survivor (NSG). Study variables were infection markers, oxygenation parameters, and risk factors obtained from patient's medical record. Bivariate and multivariate analysis were performed on all variables.

Comparison of sex and body mass index (BMI) between groups revealed no significance statistically. There was no difference in c-reactive protein (CRP) levels between NSG group with a median of 91.1 (IQR 32.3-200.45) and SG 88.95 (IQR 33.50-177.80), $P=0.899$. The risk factors for old age, diabetes mellitus DM, and increased neutrophil-lymphocyte ratio (RNL) were statistically significant in mortality between the two groups. At (NSG) the median age was 60.5 (IQR 53-67.25) vs SG 56 (IQR 35-61.25), $P=0.02$. DM SG 8 of 46 patients (17.4\%) and NSG 17 of 46 patients (37\%), $P=0.035$. On examination of NLR levels $>3.4$ NSG 42 of 46 patients $(91.3 \%)$ and NS 11 of 46 (23.9\%), $P=0.048$. Multivariate logistic regression analysis showed $P$ $/ F$ ratio is an independent risk factor. Mortality of COVID-19 patients with pneumonia (OR 0.99 95\% CI 0.988-1.00, $P=0.043$ ).

Conclusion: Age above 60 years, DM, NLR, and oxygenation index are statistically 
significant to mortality incidence in pneumonia COVID-19 patients, where low oxygenation index was correlated with higher mortality incidence.

Keywords: COVID-19; inflammation marker; mortality; oxygenation parameter; pneumonia; risk factors

\begin{abstract}
ABSTRAK
Latar Belakang: Organisasi Kesehatan Dunia (WHO) mendeklarasikan penyebaran dari coronavirus disease 2019 (COVID-19). Faktor risiko terhadap mortalitas pasien COVID-19 rawat intensive care unit (ICU) belum banyak diteliti.

Tujuan: Mengetahui hubungan penanda infeksi, penanda oksigenasi dan faktor risiko lainnya terhadap mortalitas pasien COVID-19 dengan pneumonia.

Metode: Penelitian retrospektif dilakukan di ICU Infection Centre RSUP Dr. Wahidin Sudirohusodo, Makassar pada April - Agustus 2020. Sampel penelitian adalah data pasien COVID-19 dengan pneumonia yang dirawat di ICU. Pasien dibagi ke dalam dua kelompok survivor grup (SG) dan non-survivor (NSG). Variabel penelitian berupa penanda infeksi, penanda oksigenasi dan faktor risiko yang didapatkan dari rekam medis pasien. Analisis bivariat dan multivariat dilakukan terhadap semua variabel penelitian.
\end{abstract}

Hasil: Dari 92 pasien didapatkan 46 NSG dan 46 SG. Perbandingan jenis kelamin dan indeks massa tubuh antara kedua kelompok tidak signifikan bermakna secara statistik. Tidak didapatkan perbedaan signifikan secara statistik pada level c-reactive protein (CRP) antara kelompok NSG dengan median 91,1 (IQR 32,3-200,45) dan SG 88,95 (IQR 33,50-177,80), $p=0,899$. Faktor risiko usia tua, diabetes mellitus (DM), dan peningkatan rasio neutrofil-limfosit (RNL) berdasarkan klasifikasi cut-off signifikan secara statistik pada mortalitas antar kedua kelompok. Pada NSG didapatkan median usia 60,5 (IQR 53-67,25) vs SG 56 (IQR 35-61,25), $p=0.02$. Komorbid DM SG 8 dari 46 pasien $(17,4 \%)$ dan NSG 17 dari 46 pasien $(37 \%), p=0,035$. Pemeriksaan kadar RNL berdasarkan klasifikasi cut-off $>3,4$ NSG 42 dari 46 pasien $(91,3 \%)$ dan NS 11 dari $46(23,9 \%), p=0,048$. Analisis multivariat regresi logistik didapatkan rasio $\mathrm{P} / \mathrm{F}$ merupakan faktor risiko independen. Mortalitas pasien COVID-19 dengan pneumonia (OR 0,99 95\% CI 0,988-1,00, $p=0,043$ ).

Kesimpulan: Umur di atas 60 tahun, DM, RNL, dan indeks oksigenasi bermakna secara signifikan terhadap kejadian mortalitas pasien COVID-19 dengan pneumonia, dimana pada indeks oksigenasi yang rendah didapatkan kejadian mortalitas yang tinggi.

Kata Kunci: COVID-19; faktor risiko; mortalitas; parameter oksigenasi; penanda inflamasi; pneumonia

\title{
PENDAHULUAN
}


Organisasi Kesehatan Dunia (WHO) telah mendeklarasikan kondisi gawat darurat akan penyebaran dari virus coronavirus deases 2019 (COVID-19) pada januari 2020. ${ }^{1}$ Meluasnya COVID19 ke berbagai negara dengan risiko penyebaran termasuk ke Indonesia terkait dengan adanya mobilitas dari penduduk. Maka dari itu, diperlukan lah upaya-upaya khusus dalam menangani kasus ini di Indonesia. Per 22 Februari 2021, terdapat 34.691 pasien yang meninggal karena COVID-19. ${ }^{2}$

Saat ini mulai banyak data penelitian mengenai kondisi kritis pasien dan hasil dari perawatan pasien COVID-19, namun masih sedikit diketahui mengenai faktor risiko dan kondisi kritis khusunya yang berhubungan dengan status respirasi. Indeks oksigenasi dan penanda inflamasi seperti d-dimer, ferritin, rasio netrofillimfosit, dan $C$-Reactive protein telah teridentifikasi sebagai salah satu penanda potensial dengan kondisi kritis pasien. Berbagai model penelitian untuk memprediksi faktor risiko telah dilakukan, akan tetapi pada penelitian kohort yang dilakukan masih dalam populasi kecil dan mempunyai risiko bias. ${ }^{3}$ Penelitian ini menjadi penting sehingga dapat menjadi masukan untuk keperluan manajemen pasien dan prediksi outcome pasien yang dirawat di ruang ICU di masa mendatang.

\section{METODE}

Penelitian ini menggunakan desain penelitian retrospektif yang dilakukan dengan mengambil data pasien COVID19 yang dirawat dengan pneumonia di ICU Infection Centre RSUP Dr. Wahidin Sudirohusodo Makassar mulai bulan 1 Maret - 31 Agustus 2020. Populasi yang termasuk dalam penelitian ini adalah pasien COVID-19 yang dirawat dengan pneumonia di ICU
Infection Centre RSUP Dr. Wahidin Sudirohusodo Makassar selama bulan 1 Maret-31 Agustus 2020. Sampel penelitian ini adalah data pasien COVID-19 yang dirawat di ICU infection centre, baik yang bertahan (dipindahkan ke ruang perawatan biasa) maupun yang tidak bertahan (meninggal) dalam rentang waktu 1 Maret - 31 Agustus 2020.

Data rekam medis pasien yang memenuhi kriteria inklusi untuk penelitian adalah sebagai berikut: Pasien dengan diagnosis pneumonia yang terinfeksi COVID-19 yang dikonfirmasi dengan pemeriksaan polymerase chain reaction (PCR). Dirawat inap diruang ICU infection centre di RSUP Dr. Wahidin Sudirohusodo. Data rekam medis pasien yang dieksklusi dari penelitian adalah rekam medis pasien terkonfirmasi pneumonia infeksi COVID-19 yang sulit dibaca atau tidak dilakukan pemeriksaan yang lengkap, usia dibawah 18 tahun, dan wanita hamil.

Data pasien dibagi ke dalam dua kelompok: Data pasien survivor dan non-survivor. Data yang diambil pada rekam medis mencakup identitas, umur, jenis kelamin, dan serta adanya penyakit penyerta (hipertensi, diabetes mellitus, riwayat penyakit jantung, karsinoma dan obesitas). Selain itu, data pemeriksaan penunjang pada rekam medis mencakup neutrofil, limfosit, RNL, CRP, serta hasil rasio $\mathrm{P} / \mathrm{F}$ juga diambil. Hasil pemeriksaan didapatkan dari data saat pasien dikonsul masuk ke ICU hingga pasien keluar dari Perawatan ICU atau meninggal.

Data yang diperoleh diolah dan hasilnya ditampilkan dalam bentuk narasi, tabel. Variabel numerik disajikan berupa ratarata \pm standar deviasi, jika distribusi 
data normal, dan median (kisaran interkuartil), jika distribusi data tidak normal. Variabel kategorik disajikan berupa frekuensi (persentase). Hubungan antara kelompok survivor dan non-survivor dengan variabel numerik di analisis dengan uji t-tidak berpasangan jika memenuhi syarat data berdistribusi normal. Jika data tidak memenuhi syarat, maka digunakan uji alternatif Mann-Whitney. Selanjutnya, hubungan antara kelompok survivor dan non-survivor dengan variabel kategorik (usia, jenis kelamin dan faktor komorbid) dianalisis dengan menggunakan uji Chi-Square $\left(\mathrm{X}^{2}\right)$. Syarat untuk uji Chi-Square adalah sel yang mempunyai nilai expected kurang 5 maksimal $20 \%$ dari jumlah sel. Jika syarat uji Chi-Square tidak terpenuhi maka uji alternatifnya adalah uji Fisher. Jika $\mathrm{p}<0,05$ maka hubungan dianggap signifikan.

Untuk melihat kejelasan tentang dinamika hubungan antara faktor risiko dan mortalitas dilihat melalui analisis bivariat. Uji statistik pada analisis bivariat menghasilkan nilai odds ratio (OR) untuk menentukan besar risiko determinan (variabel independen) terhadap variabel dependen. Analisis multivariat dilakukan terhadap semua variabel penelitian. Variabel yang akan diuji secara multivariat adalah variabel bebas yang dalam analisis bivariat menunjukkan kekuatan hubungan yang bermakna, atau jika tidak menunjukkan kekuatan hubungan bermakna namun variabel tersebut bila ditinjau secara teoretis mempunyai hubungan terhadap mortalitas. Semua data di analisis dengan menggunakan SPSS 25 untuk Windows.
Faktor Risiko

Pada kelompok survivor dan nonsurvivor, subjek laki-laki berjumlah 31 orang $(67,4 \%)$ dan perempuan berjumlah 15 orang $(32,6 \%)$ pada kedua kelompok. Perbandingan jenis kelamin antara kedua kelompok tidak signifikan secara statistik.

Pada kelompok survivor, median umur subjek 56 tahun (IQR 35-61,25 tahun) sedangkan median umur pada kelompok non-survivor 60,5 tahun (IQR 53-67,25 tahun). Terdapat perbedaan yang signifikan secara statistik antara kedua kelompok, di mana pada kelompok survivor didapatkan pasien dengan median dan kisaran interkuartil usia yang lebih rendah dibandingkan kelompok non-survivor. Berdasarkan kategori umur, subjek di bawah usia 60 tahun pada kelompok survivor berjumlah 32 orang $(69,6 \%)$ dan subjek berusia 60 tahun ke atas berjumlah 14 orang $(30,4 \%)$. Pada kelompok nonsurvivor, jumlah subjek berusia di bawah 60 tahun 21 orang $(45,7 \%)$ dan subjek berusia 60 tahun ke atas sebanyak 25 orang (54,3\%). Subjek penelitian yang dimasukkan ke dalam penelitian ini menunjukkan jumlah pasien kelompok usia 60 tahun ke atas lebih besar pada kelompok non-survivor dibandingkan dengan kelompok survivor.

Median indeks massa tubuh (IMT) subjek pada kelompok survivor 23,55 $\mathrm{kg} / \mathrm{m}^{2}$ (IQR 21,48-25,39 $\mathrm{kg} / \mathrm{m}^{2}$ ) dan pada kelompok non-survivor 23,53 $\mathrm{kg} / \mathrm{m}^{2} \quad$ (IQR 21,61-35,39 $\mathrm{kg} / \mathrm{m}^{2}$ ). Analisis statistik pada variabel tersebut menunjukkan perbedaan yang tidak signifikan.

\section{HASIL}


Dari 46 subjek pada kelompok survivor, 14 orang memiliki komorbid hipertensi, 8 orang memiliki komorbid DM, 6 orang memiliki komorbid penyakit jantung, 3 orang yang memiliki komorbid chronic kidney disease (CKD) atau gagal ginjal kronis, dan tidak ada subjek dengan komorbid merokok. Pada kelompok non-survivor, 19 orang memiliki komorbid hipertensi,
17 orang memiliki komorbid DM, 9 orang dengan komorbid penyakit jantung, 8 orang dengan komorbid CKD, dan 4 orang dengan komorbid merokok. Analisis statistik pada variabel ini tidak menunjukkan perbedaan yang signifikan, kecuali pada komorbid DM. Perbandingan komorbid ditampilkan pada Gambar 1.

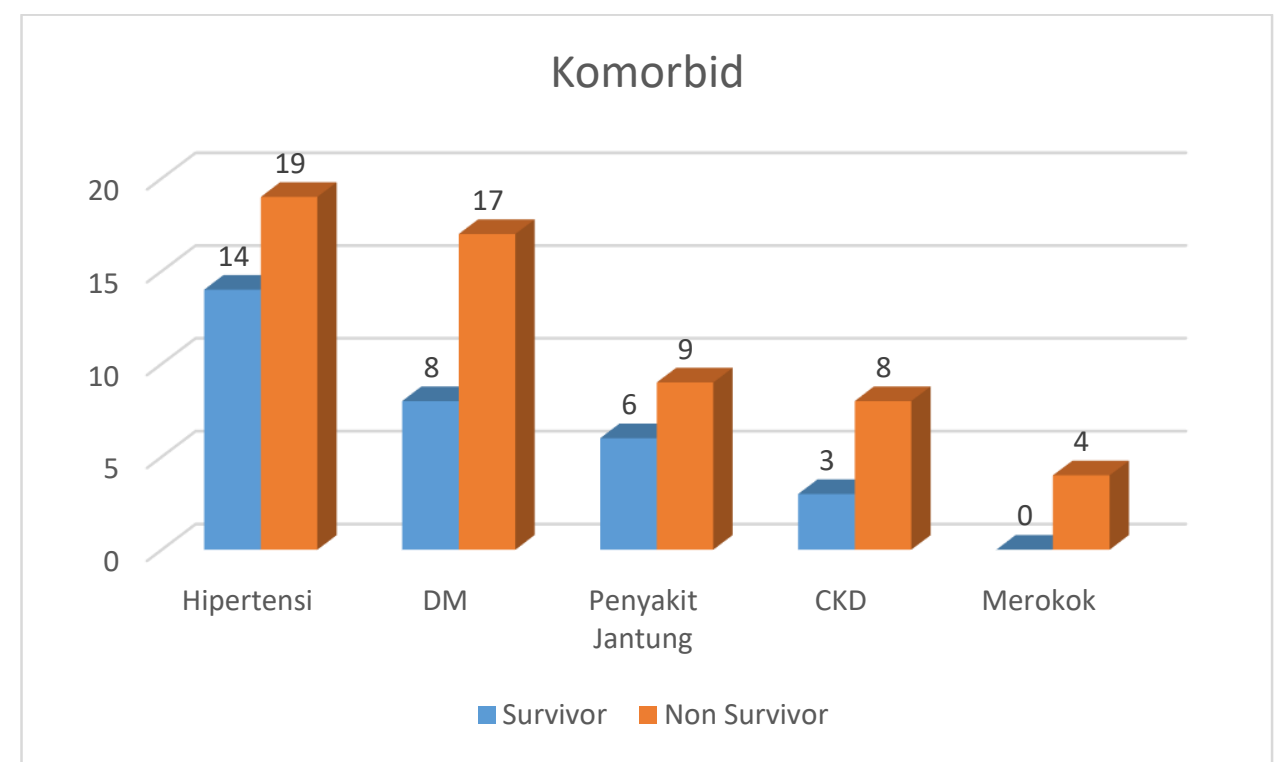

Gambar 1. Perbandingan komorbid pada grafik menunjukkan subjek dengan komorbid DM, hipertensi, penyakit jantung, CKD dan perokok ditemukan lebih banyak pada kelompok non-survivor dibandingkan kelompok survivor

Kadar Neutrofil

Median kadar neutrofil saat masuk ICU pada kelompok survivor sebesar $81,7 \%$ (IQR 68,13-89,20\%). Pada kelompok non-survivor, median kadar neutrofil lebih tinggi dibanding kelompok survivor, yaitu sebesar $84,45 \%$ (IQR $75,6-88,33 \%$ ) tetapi tidak signifikan secara statistik.

Kadar Limfosit

Median kadar limfosit kelompok survivor saat masuk ICU sebesar 9,15\% (IQR 5,35-18,15\%). Median kadar limfosit kelompok non-survivor 9,3\% (IQR 6,78-14,45\%). Tidak terdapat perbedaan signifikan antara kedua kelompok.
Rasio neutrofil-limfosit ( $R N L$ )

Median RNL saat masuk ICU pada kelompok survivor sebesar 8,94 (IQR 3,41-17,35), sedangkan pada kelompok non-survivor sebesar 8,75 (IQR 5,5313,12). Perbandingan RNL ini tidak bermakna secara statistik. Klasifikasi RNL berdasarkan nilai cut-off 3,4 didapatkan 11 subjek (23\%) memiliki RNL di bawah 3,4 dan 35 subjek dengan RNL 3,4 ke atas pada kelompok survivor. Pada kelompok non-survivor, 4 subjek $(8,7 \%)$ memiliki RNL di bawah 3,4 dan 42 subjek $(91,3 \%)$ memiliki RNL 3,4 ke atas. Perbandingan kedua kelompok berdasarkan klasifikasi RNL 
menunjukkan perbedaan yang bermakna secara statistik.

\section{Kadar CRP}

Median kadar CRP kelompok survivor saat masuk ICU 88,95 $\mathrm{mg} / \mathrm{L}$ (IQR 33,50-177,80 $\mathrm{mg} / \mathrm{L})$, lebih rendah daripada kelompok non-survivor 91,1 $\mathrm{mg} / \mathrm{L} \quad$ (32,3-200,45 mg/L), meskipun tidak signifikan secara statistik.

Parameter Oksigenasi

Rasio P/F menggambarkan parameter oksigenasi. Pada kelompok survivor, median rasio $\mathrm{P} / \mathrm{F}$ saat masuk ICU sebesar 175 (119,43-251,17) sedangkan pada kelompok non-survivor sebesar 138,1 (106,93-189,54). Perbandingan rasio $\mathrm{P} / \mathrm{F}$ ini tidak signifikan secara statistik.
Analisis Multivariat

Tabel 1 menjabarkan hasil analisis multivariat pada penelitian. Terdapat enam variabel yang memenuhi syarat untuk dilakukan analisis regresi logistik, yaitu kelompok umur, lama perawatan, intubasi, DM, CKD, dan rasio P/F. Dari analisis multivariat, terlihat bahwa variabel kelompok umur (crude OR $0,422 ; 95 \%$ CI $0,157-1,134)$, lama perawatan (crude OR 0,926; 95\% CI 0,847-1,013), intubasi (crude OR 0,453; 95\% CI 0,139-1,474), DM (crude OR $0,441 ; 95 \%$ CI $0,144-1,353)$, CKD (crude OR 0,265; 95\% CI 0,042-1,652), dan rasio P/F (OR 0,994; 95\% CI 0,998$1,000)$ memiliki korelasi negatif dengan luaran (survivor dan non-survivor). Dari keenam variabel tersebut, hanya rasio $\mathrm{P} / \mathrm{F}$ signifikan secara statistik.

Tabel 1. Analisis multi variat

\begin{tabular}{llccc}
\hline \multirow{2}{*}{ No. } & Variabel & $\beta$ & Bivariate & \\
\cline { 4 - 5 } & & & Crude OR $(95 \%$ CI $)$ & Nilai $p$ \\
\hline 1 & Kelompok umur & $-0,864$ & $0,422(0,157-1,134)$ & 0,087 \\
\hline 2 & Lama perawatan & $-0,077$ & $0,926(0,847-1,013)$ & 0,093 \\
\hline 3 & Intubasi & $-0,793$ & $0,453(0,139-1,474)$ & 0,188 \\
\hline 4 & DM & $-0,818$ & $0,441(0,144-1,353)$ & 0,153 \\
\hline 5 & CKD & $-1,328$ & $0,265(0,042-1,652)$ & 0,155 \\
\hline 6 & P/F ratio & $-0,006$ & $0,994(0,998-1,000)$ & $0,043^{*}$ \\
\hline
\end{tabular}

\section{PEMBAHASAN}

Faktor Risiko

Pada kelompok survivor dan nonsurvivor, subjek laki-laki berjumlah lebih banyak daripada perempuan. Penelitian pendahuluan pertama yang meneliti peran jenis kelamin terhadap morbiditas dan mortalitas pada pasien COVID-19 menunjukkan pasien lakilaki dengan COVID-19 lebih berisiko mengalami luaran yang buruk dan kematian, terlepas dari usianya. ${ }^{4}$ Beberapa penelitian lain melaporkan laju mortalitas COVID-19 yang lebih tinggi pada laki-laki. ${ }^{5}$

Volume 13, Nomor 2, Tahun 2021
Pada kelompok survivor, didapatkan pasien dengan median dan kisaran interkuartil usia yang lebih rendah dibandingkan kelompok non-survivor. Berdasarkan kategori umur, subjek berusia 60 tahun ke atas pada kelompok non-survivor lebih banyak dibandingkan pada kelompok survivor. Hal ini sesuai dengan penelitian mengenai risiko insidens dan mortalitas COVID-19 di Provinsi Hubei dan beberapa tempat lain di Cina, di mana didapatkan risiko insidens yang relatif rendah untuk usia muda tetapi risiko mortalitas yang sangat tinggi untuk orang tua. ${ }^{4}$ Hasil serupa didapatkan pada penelitian oleh Iaccarino dkk yang 
menunjukkan usia dan komorbid merupakan determinan kematian yang paling penting pada pasien COVID-19. ${ }^{6}$ Hasil serupa juga didapatkan pada penelitian oleh $\mathrm{Wu} \mathrm{dkk}$, usia lanjut berhubungan dengan risiko terjadinya acute respiratory distress syndrome (ARDS) dan kematian yang lebih besar, kemungkinan dikarenakan respons imun yang kuat. ${ }^{7}$

Terdapat hubungan yang mencolok antara IMT dengan risiko kematian pada pasien dengan diagnosis COVID19 pada sistem layanan kesehatan terintegrasi. Hubungan ini bersifat independen pada komorbid terkait obesitas dan perancu potensial lainnya. Obesitas berat, khususnya pada pasien muda, melampaui risiko mortalitas yang dimiliki keadaan terkait obesitas lainnya, seperti riwayat infark miokardium, DM, hipertensi, atau hiperlipidemia, yang menunjukkan hubungan patofisiologis signifikan antara kelebihan adipposit dengan penyakit COVID-19 berat. Penelitian Lippi dkk mendapatkan Analisis yang dikumpulkan dari literatur saat ini menunjukkan bahwa hipertensi dapat dikaitkan dengan risiko COVID-19 parah atau fatal hingga 2,5 kali lipat lebih tinggi, terutama pada orang yang lebih tua. ${ }^{8}$ Mehra dkk juga mengkonfirmasi pengamatan sebelumnya yang menunjukkan bahwa penyakit kardiovaskular yang mendasari dikaitkan dengan peningkatan risiko kematian di rumah sakit di antara pasien yang dirawat di rumah sakit dengan COVID-19. Tidak mengkonfirmasi kekhawatiran sebelumnya mengenai hubungan yang berbahaya antara penghambat ACE atau ARB dengan kematian di rumah sakit dalam konteks klinis ini. ${ }^{9}$ Penyakit Ginjal sendiri, terkhusus pada pasien dengan CKD di ungkapkan oleh Cheng dkk pada penelitian di Wuhan bahwa pasien dengan peningkatan kreatinin serum awal lebih cenderung dirawat di unit perawatan intensif dan menjalani ventilasi mekanis, menunjukkan bahwa penyakit ginjal saat masuk menunjukkan risiko mortalitas yang lebih tinggi. ${ }^{10}$ Selain penyakit kronik, adiposit viseral juga mendorong peningkatan mortalitas pada pasien sakit kritis dengan ARDS. Akan tetapi, pada penelitian ini tidak didapatkan perbedaan yang signifikan pada IMT kedua kelompok dan variabel IMT tidak memenuhi syarat untuk dilakukan analisis regresi logistik.

Pada pasien dengan faktor risiko perokok tidak didapatkan perbedaan bermakna. Seperti yang diungkapkan oleh Reddy dkk menyimpulkan pada Covid-19 merokok dan tidak merokok sama-sama meningkatan risiko mortalitas. $^{11}$

Pada penelitian ini, subjek dengan komorbid DM ditemukan lebih banyak pada kelompok non-survivor dan perbedaannya signifikan secara statistik. Hal ini sesuai dengan temuan sebuah meta-analisis menunjukkan bahwa pasien diabetes dengan infeksi COVID19 memiliki risiko yang lebih tinggi untuk masuk ICU selama terinfeksi. Selain itu, DM meningkatkan risiko mortalitas selama terinfeksi COVID19. ${ }^{12}$ DM umumnya berhubungan dengan progonosis penyakit infeksi yang buruk, tetapi hingga saat ini baru terbukti pada beberapa laporan berbeda pada pasien COVID-19 dan belum dianalisis secara komprehensif. Data yang ada menunjukkan bahwa pasien DM memiliki risiko komplikasi yang lebih tinggi. ${ }^{13}$ Pada penelitian lain, diabetes berhubungan dengan peningkatan insidens dan derajat keparahan COVID-19. Terdapat bukti 
eksperimental mengenai efek DM terhadap masuknya virus ke dalam sel dan respons inflamasi terhadap infeksi. Penting untuk mengontrol gula darah pada pasien dengan COVID-19. ${ }^{13}$

Penanda Inflamasi

Hasil penelitian ini menunjukkan hitung neutrofil yang jauh di atas normal pada kedua kelompok, meskipun tidak berbeda signifikan antara kedua kelompok. Peningkatan hitung neutrofil ini sesuai dengan penelitian oleh Li dkk yang menunjukkan bahwa hitung neutrofil yang tinggi secara independen memprediksi terjadinya sakit kritis. ${ }^{14}$ Peningkatan neutrofil menunjukkan kemungkinan infeksi bakteri atau respons inflamasi non-infeksius. Neutrofil yang lebih tinggi juga dapat menjadi cerminan inflamasi berlebihan. ${ }^{15}$

Pada penelitian ini, perbandingan hitung limfosit tidak menunjukkan perbedaan yang signifikan secara statistik antara kedua kelompok. Hal ini berbeda dengan temuan sebuah meta-analisis yang menunjukkan bahwa hitung limfosit yang lebih rendah berhubungan dengan peningkatan mortalitas, ARDS, kebutuhan perawatan ICU, dan COVID19 berat. Hubungan ini tampaknya lebih kuat pada pasien yang lebih muda dibandingkan pasien lansia. ${ }^{16}$ Beberapa penelitian sebelumnya menunjukkan perbedaan hitung limfosit yang signifikan antara pasien COVID-19 dengan kasus berat dan tidak berat, antara pasien ICU dan non-ICU, serta antara survivor dan non-survivor. Mekanisme yang menyebabkan limfopenia pada pasien COVID-19 belum jelas tetapi dapat meliputi kematian limfosit yang disebabkan oleh infeksi virus, kerusakan organ limfatik (seperti timus dan lien) akibat infeksi virus langsung, apoptosis limfosit yang diinduksi oleh sitokin-sitokin inflamasi, inhibisi limfosit akibat asidosis metabolik, dan translokasi limfosit dari darah perifer terhadap organ target seperti paru. Baik hitung limfosit yang lebih rendah dan persentase limfosit yang lebih rendah berhubungan kuat dengan keparahan penyakit, juga memprediksi progresi penyakit kritis. Pada penelitian lain, hitung limfosit yang rendah pada saat masuk rumah sakit merupakan prediktor independen dari kasus kritis atau progresi ke penyakit kritis. ${ }^{17}$

Pada penelitian ini, nilai RNL antara kedua kelompok tidak signifikan secara statistik. Namun, ketika dikelompokkan berdasarkan nilai cut-off (di atas atau di bawah cut-off), kelompok non-survivor yang lebih memiliki nilai RNL di melebihi nilai cut-off RNL $(3,4)$ memiliki perbedaan yang signifikan secara statistik dibandingkan kelompok non-survivor. Hasil ini sesuai dengan temuan dari ulasan sistematik dan metaanalisis oleh Li dkk, di mana RNL memiliki nilai prediktif terhadap derajat keparahan penyakit dan mortalitas pada pasien dengan infeksi COVID-19. Mengevaluasi RNL dapat membantu mengidentifikasi dini potensi kasus berat, melakukan triase dini, dan memulai manajemen efektif tepat waktu, yang dapat mengurangi keseluruhan mortalitas COVID-19. ${ }^{18}$ Penelitian oleh Shang dkk mengenai parameter klinis dalam memprediksi derajat keparahan COVID-19, RNL, CRP, dan trombosit dapat menilai derajat keparahan COVID-19 secara efektif, di mana RNL merupakan prediktor terbaik dari COVID-19 berat. ${ }^{19}$ Akan tetapi, pada penelitian ini nilai $\mathrm{p}$ RNL tidak memenuhi syarat untuk dilakukan regresi logistik sehingga tidak dapat dinilai hubungannya dengan luaran. 
Perbandingan kadar CRP tidak signifikan secara statistik pada penelitian ini, tetapi pada kelompok survivor kadar CRP lebih rendah. Pernan dari CRP pada penyakit ini melibatkan inflamasi yang berlebihan dan sel imun inang. ${ }^{20}$ Pada penelitian oleh Yamada dkk, demam, leukositosis, dan peningkatan CRP berhubungan dengan luaran kritis. Leukopenia berhubungan dengan prognosis yang lebih baik. Sama halnya yang diungkapkan oleh Xiaomin dkk pada penelitian di Wuhan ditemukan bahwan CRP menjadi predictor yang tepat menjadi luaran pasien COVID-19. ${ }^{21}$ Selain itu, leukositosis dan peningkatan CRP pada saat masuk rumah sakit dapat memprediksi luaran yang buruk. ${ }^{22}$ Pada penelitian oleh Luo dkk, kadar CRP serum saat masuk rumah sakit dapat membedakan dengan baik derajat keparahan pasien dan memprediksi luaran berbahaya pada pasien dengan COVID-19. ${ }^{15}$ Pasien dengan peningkatan CRP bermakna saat masuk rumah sakit harus diberikan perhatian lebih dan terapi yang lebih kuat. ${ }^{23}$ Akan tetapi, pada penelitian ini tidak dapat dilakukan regresi logistik pada variabel CRP sehingga tidak dapat dievaluasi mengenai hubungannya dengan luaran.

Parameter Oksigenasi

Pada kelompok survivor didapatkan rasio $\mathrm{P} / \mathrm{F}$ yang lebih tinggi dibandingkan kelompok non-survivor meskipun perbedaanya tidak bermakna secara statistik. Pada penelitian oleh Hernandez-Romieu menunjukkan, berdasarkan rasio $\mathrm{P} / \mathrm{F}, 43 \%$ subjek dengan rasio $\mathrm{P} / \mathrm{F} \leq 100,33 \%$ dengan rasio $\mathrm{P} / \mathrm{F}$ 101-200, dan $39 \%$ dengan rasio P/F 201-300. Tidak ada kecenderungan yang tampak antara komplians statis awal dengan mortalitas, dan penurunan komplians tidak berhubungan dengan proporsi mortalitas yang lebih tinggi. ${ }^{24}$ Pada penelitian oleh COVID-UPO Clinical Team dan Sainaghi di Italia, rasio $\mathrm{P} / \mathrm{F}$ lebih rendah secara signifikan pada pasien non-survivor dibandingkan dengan survivor, yang mengidentifikasi gagal napas yang lebih besar dibandingkan survivor pada keadaan basal (246 [184-300] vs 126 [100-202], $\mathrm{p}<0,001)$. Mortalitas rawat inap juga berhubungan dengan hitung neutrofil yang lebih tinggi dan peningkatan kreatinin serum, CRP, dan laktat dehydrogenase $(\mathrm{LDH}){ }^{25}$

Pada model multivariabel yang meliputi variabel-variabel laboratorium yang paling relevan, rasio $\mathrm{P} / \mathrm{F}$ merupakan satu-satunya yang mengkonfirmasi potensi peran prediktifnya. Selain itu, rasio $\mathrm{P} / \mathrm{F}$ dikonfirmasi dapat memprediksi mortalitas, bersama dengan umur, pada model multivariabel lebih lanjut yang meliputi demografi dan variabel-variabel klinis. ${ }^{25}$ Analisis multivariat pada penelitian ini juga menunjukkan korelasi negatif antara rasio $\mathrm{P} / \mathrm{F}$ dengan luaran dengan crude OR 0,265 (CI 0,042-1,652), dan merupakan satu-satunya variabel yang menunjukkan signifikansi secara statistik.

\section{KESIMPULAN}

Umur di atas 60 tahun, komorbid DM, RNL dan indeks oksigenasi bermakna secara signifikan terhadap kejadian mortalitas pasien COVID-19 dengan pneumonia. Indeks oksigenasi merupakan variabel independen yang paling besar hubungannya dengan mortalitas pasien COVID-19 dengan pneumonia, dimana pada indeks oksigenasi yang rendah didapatkan kejadian mortalitas yang tinggi. Diperlukan penelitian lebih lanjut dengan jumlah subjek yang lebih besar dan penelitian kohort prospektif untuk 
menilai hubungan faktor risiko, penanda inflamasi, dan penanda oksigenasi dengan mortalitas pada pasien COVID19 dengan pneumonia.

\section{DAFTAR PUSTAKA}

1. Qin C, Zhou L, Hu Z, Zhang S, Yang S, Tao Y, et al. Dysregulation of immune response in patients with coronavirus 2019 (COVID-19) in Wuhan, China. Clin Infect Dis. 2020; 20(20):4-10.

2. Kementerian Kesehatan RI. Pedoman pencegahan dan pengendalian coronavirus disesase Indonesia. 2020.

3. Haimovich A, Ravindra NG, et al. Development and validation of the COVID-19 severity index (CSI): a prognostic tool for early respiratory decompensation. medRxiv [Internet].

2020;2020.05.07.20094573.

Available from: http://medrxiv.org/content/early/20 20/05/14/2020.05.07.20094573.abst ract

4. Li H, Wang S, Zhong F, Bao W, Li Y, Liu L, et al. Age-dependent risks of incidence and mortality of COVID-19 in Hubei province and other parts in China. Front Med. 2020;7(190):1-6.

5. Islam N, Khunti K, Dambha-Miller H, Kawachi I, Marmot M. COVID19 mortality: a complex interplay of sex, gender, and ethnicity. Europe J Pub Health. 2020;30(5):847-8.

6. Iaccaroni G, Grassi G, Borghi C, Ferri C, Salvetti M, et al. Age and multimorbidity predict death among COVID-19 patients; results of the SARS-RAS study of the Italian society of hypertension. Hypertension. 2020;1-

7. Tartof SY, Qian L, Hong V, Wei R, Nadjafi RF, Fischer $H$, et al.
Obesity and mortality among patients diagnosed with COVID19: results from an integrated health care organization. Annals Intern Med. 2020;1-10.

8. Lippi G, Wong J, Henry BM. Hypertension and its severity or mortality in coronavirus disease 2019 (COVID-19): a pooled analysis. Polish Arch Intern Med. 2020;1-22

9. Mehra MR, Desai SS, Kuy SR, Henry TD, Patel AN. Cardiovascular disease, drug therapy, and mortality in Covid-19. New Eng J Med. 2020;1-8.

10. Cheng Y, Luo R, Wang K, Yao Y, Ge $\mathrm{S}, \mathrm{Xu}$ G. kidney disease is associated with in-hospital death of patients with COVID-19. Kidney Inter. 2020;97(5):P829-38.

11. Reddy RK, Charles WN, Sklavounos A, Dutt A, Seed PT, Khajuria A. The effect of smoking on COVID-19 severity: a systematic review and metaanalysis. J Med Virol. 2020;1-12.

12. Roncon L, Zuin M, Rigatelli G, Zuliani G. Diabetic patients with COVID-19 infection are at higher risk of ICU admission and poor short-term outcome. J Clin Virol. 2020;127:1-5.

13. Singh AK, Gupta R, Ghosh A, Misra A. Diabetes in COVID-19: prevalence, pathophysiology, prognosis and practical considerations. Diabet Metab Synd: Clin Res Rev. 2020;14:303-10.

14. Li N, Kong H, Zheng XZ, Li XY, Ma J, Zhang $H$, et al. Early predictive factors of progression from severe type to critical ill type 
in patients with coronavirus disease 2019: a retrospective cohort study. Plos One. 2020;1-13.

15. Seyit M, Avci E, Nar R, Senol H, Yilmaz A, Ozen M, Oskay A, Aybek H. Neutrophil to lymphocyte ratio, lymphocyte to monocyte ratio and platelet to lymphocyte ratio to predict the severity of COVID-19. Am J Emerg Med. 2021

16. Huang I, Pranata R. Lymphopenia in severe coronavirus disease-2019 (COVID-19): systematic review and meta-analysis. J Intens Care. 2020;8(36):1-10.

17. Lin S, Mao W, Zou Q, Lu S, Zheng S. Associations between hematological parameters and disease severity in patients with SARS-CoV-2 infection. J Clin Lab Anal. 2021 Jan;35(1):e23604. doi: 10.1002/jcla.23604. Epub 2020 Nov 13. PMID: 33184946; PMCID: PMC7843261.

18. Li N, Kong H, Zheng XZ, Li XY, Ma J, Zhang $\mathrm{H}$, et al. Early predictive factors of progression from severe type to critical ill type in patients with Coronavirus Disease 2019: a retrospective cohort study. Plos One. 2020;1-13.

19. Shang W, Dong J, Ren Y, Tian M, $\mathrm{Li} \mathrm{W}, \mathrm{Hu}$ J. the value of clinical parameters in predicting the severity of COVID-19. J Med Virol. 2020;92(10):2188-92.
20. Ma A, Cheng J, et al. Neutrophil-tolymphocyte ratio as a predictive biomarker for moderate-severe ARDS in severe COVID-19 patients. Crit Care. 2020;24(1):288.

21. Xiaomin L, Wei Z, et al. Prognostic value of $\mathrm{C}$-reactive protein in patients with COVID-19, Clinical Infectious Diseases, , ciaa641, Oxford University Press for the Infectious Diseases Society of America; 2020. p. 1-21.

22. Luzy L, Radaelli MG. Influenza and obesity: its odd relationship and the lessons for COVID-19 pandemic. Acta Diabetologica.2020(57);75964

23. Yamada $T$, Wakabayashi $M$, Yamaji T, Chopra N, Mikami T, Miyashita $H$, et al. Value of leukocytosis and elevated $C$ Reactive protein in predicting severe coronavirus

24. Hernandez-Romieu AC, Adelman MW, Hockstein MA, Robichaux CJ, Edwards JA, Fazio JC, et al. timing of intubation and mortality among critically ill coronavirus disease 2019 patients: a singlecenter cohort study. 2020;48(11):e1045-53.

25. COVID-UPO Clinical Team, Sainaghi PP. Fatality rate and predictors of mortality in a large Italian cohort of hospitalized COVID-19 patients. Res Squar. 2020;1-19. 